\title{
A NEED ANALYSIS OF ENGLISH FOR SPECIFIC PURPOSES (ESP) FOR NURSING STUDENTS AT SMKS KESEHATAN KENDARI
}

\author{
Ria Z. Wulandari ${ }^{1}$ Muh. Khusnun Muhsin ${ }^{2}$ Tambunan $^{3}$
}

${ }^{1}$ Halu Oleo University, Indonesia.

\begin{tabular}{l} 
ARTICLE INFO \\
\hline Keywords: \\
English for \\
Purposes $\quad$ (ESP), \\
Need $\quad$ Analysis, \\
Target $\quad$ Situation \\
Analysis $\quad$ (TSA), \\
Nursing Students \\
How to cite: \\
\\
DOI:
\end{tabular}

ABSTRACT
English for Specific Purposes (ESP) has been discussed for a
long time around the world in the field of English Language
Teaching (ELT). Teaching English based on students' needs
is important, particularly for those learners who learn
English beyond the academic purposes such as vocational
high school students. The objective of this study is to analyse
nursing students' needs for ESP materials at SMKS
Kesehatan Kendari based on Target Situation Analysis.
Therefore, this study is conducted to identify the Target
Situation Analysis (TSA) of one of vocational high school in
Kendari. This study employed research and development
design with 22 samples. The data obtained from
questionnaire were analysed statistically by using SPSS
version 16.0. The result shows that students need in learning
English process for the tasks of speaking skill; how to ask
question English well, how to answer question English well,
do communication with schoolmates, do communication
with teachers, and do communication with patients.
Listening skill; listening and understanding when do face to
face conversations, listening and understanding through
conversation on the phone, listening and understanding the
content of forum discussions, and listening and
understanding the content of announcements. Reading skill;
how to read health magazine, how to read announcement,
and how to read patient list, and Writing skill; how to fill the
patients form and how to write medical report. Based on the
findings, it concludes that speaking and listening skills are
the most needed by nursing students in order to
communicate in English.




\section{Introduction}

The growth of English as a Lingua Franca (ELF) along with increased mobility of populations around the world has created the wider use of English in many fields of studies and occupations. The needs of English, particularly in the strategic fields such as healthcare becomes inevitable in this globalizations era (Bensoussan, et al., 2009). Finch (2014) argues that even in EFL countries, which the first language is not English, the need for English, especially Medical English becomes crucial. The healthcare professionals need to use English in order to read professional journals, attend international conferences, communicate with international colleagues, and treat English-speaking patients who are visiting, residing, or doing business in the country. Based on the above background, the researcher poses the research question as follows: "What are the ESP needs of nursing students at SMKS Kesehatan Kendari based on Target Situation Analysis?”. The objective of the study is to analyze nursing students' need in learning English process at SMKS Kesehatan Kendari based on Target Situation Analysis.

\section{Literature Review}

English for Specific Purposes (ESP) has grown to become one of the most prominent areas of English as Foreign Language (EFL) teaching today (Asfihana, 2017). This process cannot be separated from the growth of English as a Lingua Franca (ELF) and the wider use of English in many fields of studies and occupations. ESP has become increasingly important since more and more people are using English in a growing number of occupational contexts (Asfihana, 2017). The expansion of demand for English to suit specific needs of a profession has emerged the great challenges for EFL teacher to provide English language teaching that can meet the learner goals in real occupation world. Therefore, the idea of adopting ESP in the classrooms particularly in Indonesia both at schools and universities cannot be avoided (Poedjiastutie, 2017).

Furthermore, teaching English for Specific Purposes has raised many issues among EFL teachers (Asfihana, 2017). These issues related to the importance of ESP and the teachers' skill to implement it in the EFL classroom. Some people claim that EFL teachers do not possess the necessary knowledge of the subject matter, and therefore he/she may not be able to exchange ideas which contribute to bring about the intended learning outcomes. Poedjiastutie (2017) points out that the adoption of ESP emerges many issues in EFL teaching that may become barriers for English language teaching and learning process. These 
issues related to communicative language teaching and teachers' lack of knowledge and skills. Furthermore, the implementation of ESP in EFL teaching is also limited to the readiness of English teacher. The lack of teachers' knowledge about ESP becomes obstacles to fully implement it in EFL classroom. Marwan (2009) stated that the adoption of ESP is mostly not accompanied by understanding the principles of ESP. The teacher-centered method in EFL teaching classroom has become problems for teacher to implement ESP. Most teachers view English language teaching in general context where students are taught to know the English materials and to pass the examination. In this case, students' need of English for their specific goals and interest to support their future study and profession are neglected.

The Vocational high school in Indonesia. Then, since training and education programs at SMK are aimed at enabling students to assess certain competence in order to encourage them to get jobs dealing with national welfare (Schippers \& Patriana, 1994), the English teaching at SMK must be directed at reaching the aim. The issue of English teaching, in this case concerns with how to provide English to meet learners needs. ESP, then, becomes an essential approach in English language teaching. When English is used for special purposes, there should be a particular program for learners in order to learn it effectively. To set up a program for ESP, a teacher has to concern with several points: teaching guideline, syllabus, selecting a good materials selection for ESP program, the objectives and the students. Along with this program, good teachers will set up a program (teaching guidelines) before they begin teaching. These programs are necessary because they can prepare all the teaching and learning activities. When they do this, they can make an evaluation for the teaching materials and they can eliminate a repetition of the same materials that can cause students' boredom.

\section{Research Methodology}

This study used a research and development design that describes the students' needs in learning English for nursing students at SMKS Kesehatan Kendari. It is in fact used to obtain information concerning the current status of the phenomena and to describe what exists. According to Borg and Gall (1989) educational research and development is a process used to develop and validate educational product. The R and D design in this current study applied to describe the Target Situation Analysis (TSA) to analyse the ESP materials that

nursing students needs of SMKS Kesehatan Kendari in their English learning process. The Closed-ended questionnaires in this study administrated to find out students' perception to 
their needs for the ESP materials of speaking, listening, reading and writing skills for nursing students and the interview of teacher and students were conducted to deepen researcher's understanding about students' needs as well as to support the arguments provided in this study.

\section{Finding and Discussion}

a. Speaking Skill

\begin{tabular}{|c|l|c|c|}
\hline No. & \multicolumn{1}{|c|}{ Items } & Means & Category \\
\hline 1. & How to ask questions English well & $\mathbf{4 . 5 9}$ & Need \\
\hline 2. & How to answer questions English well & $\mathbf{4 . 5 0}$ & Need \\
\hline 3. & Do communication with non native speakers & 2.36 & No need \\
\hline 4. & Do communication with schoolmates & $\mathbf{3 . 6 8}$ & Need \\
\hline 5. & Do communication with teachers & $\mathbf{3 . 8 1}$ & Need \\
\hline 6. & Do communication with patients & $\mathbf{3 . 6 3}$ & Need \\
\hline 7. & Do communication with doctors & 3.40 & No need \\
\hline 8. & How to communicate in the hospital & 3.40 & No need \\
\hline 9. & How to communicate in the emergency room & 3.09 & No need \\
\hline
\end{tabular}

The means score showed students' needs for the tasks include five options of the questionnaire were how to ask questions English well, how to answer questions English well, do communication with teachers, do communication with schoolmates, and do communication with patients. Students felt that the tasks are needed because as a nurse, they always do directly communication with patients and doctor.

b. Listening Skill

\begin{tabular}{|c|l|c|c|}
\hline No. & \multicolumn{1}{|c|}{ Items } & Means & Category \\
\hline 10. & $\begin{array}{l}\text { Listening and understanding native speakers } \\
\text { speak }\end{array}$ & 3.45 & No Need \\
\hline 11. & $\begin{array}{l}\text { Listening and understanding non-native } \\
\text { speakers speak }\end{array}$ & 2.72 & No Need \\
\hline 12. & $\begin{array}{l}\text { Listening and understanding the content of } \\
\text { health broadcast in the radio }\end{array}$ & 3.18 & No Need \\
\hline 13. & $\begin{array}{l}\text { Watching and understanding the main point on } \\
\text { TV program health shows }\end{array}$ & 3.31 & No Need \\
\hline 14. & $\begin{array}{l}\text { Listening and understanding the contents of } \\
\text { announcements }\end{array}$ & $\mathbf{3 . 5 9}$ & Need \\
\hline 15. & $\begin{array}{l}\text { Watching and understanding the content films } \\
\text { of health }\end{array}$ & 3.40 & No Need \\
\hline 16. & $\begin{array}{l}\text { Watching and understanding of health } \\
\text { seminars }\end{array}$ & 3.31 & No Need \\
\hline
\end{tabular}




\begin{tabular}{|c|l|c|c|}
17. & $\begin{array}{l}\text { Listening and understanding the content of } \\
\text { forum discussions }\end{array}$ & $\mathbf{3 . 7 7}$ & Need \\
\hline 18. & $\begin{array}{l}\text { Listening and understanding the } \\
\text { conversations through phone }\end{array}$ & $\mathbf{3 . 8 6}$ & Need \\
\hline 19. & $\begin{array}{l}\text { Listening and understanding when do face } \\
\text { to face conversations }\end{array}$ & $\mathbf{4 . 4 0}$ & Need \\
\hline
\end{tabular}

The means score showed students need of listening skill for the tasks include four options of questionnaire were listening and understanding when do face to face conversations, listening and understanding the conversations through phone, listening and understanding the content of forum discussions, listening and understanding the contents of announcements.

c. Reading Skill

\begin{tabular}{|c|l|c|c|}
\hline No. & \multicolumn{1}{|c|}{ Items } & Means & Category \\
\hline 20. & How to read health magazine & 4.18 & Need \\
\hline 21. & How to read announcement & 3.81 & Need \\
\hline 22. & How to read patients List & 3.77 & Need \\
\hline
\end{tabular}

The means score showed students need of reading skill for the tasks include three options of questionnaire were how to read health magazine, how to read announcement, and how to read patients list.

d. Writing Skill

\begin{tabular}{|c|l|c|c|}
\hline No. & \multicolumn{1}{|c|}{ Items } & Means & Category \\
\hline 23. & How to write announcement & 3.45 & No Need \\
\hline 24. & How to write medical report & 4.13 & Need \\
\hline 25. & How to fill the patients form & 4.27 & Need \\
\hline
\end{tabular}

The means score showed students need for the tasks include two options items of questionnaire how to fill the patients form and how to write medical report.

The result for four language skills are that language skill is very influential on vocational school. Every vocational school has different learning needs and they need their own material directed to the major of the school. It is line with Richards (2001) who argues that the different types of the students have different language needs and what they are taught should be restricted to what they need. Therefore, the teacher has to starts with analysis to know students' needs to their target situations. In fact, the role of the teacher in an ESP setting is highly significant. ESP teachers' help their students develop specialized language 
skills that will allow them to function and potentially excel in their professional lives. They also prepare their students to pursue academic competence independently (Ghafounia \& Sabet, 2014, pg. 1 citied Mulleneaux, 2017, pg. 13).

\section{Conclusion}

The result of this study revealed that students' needs of target situation analysis (TSA) are there are fourteen items that students need to learn in English subject of English for Specific Purposes (ESP). They felt that learn ESP is not only important but also needed for nursing students. In fact, speaking and listening skill are the most needed by nursing student in order to communicate in English. So that communication skill of students should be improved.

\section{References}

Arikunto, Suharsini. (2008). Dasar-Dasar Evaluasi Pendidikan. Jakarta: Bumi Aksara.

Asfihana, R. (2017). Teaching English For Specific Purposes (ESP) In EFL Context. LET: Linguistics, Literature And English Teaching Journal, 3(1), 24-33

Bae, D. (2017). Designing An English Syllabus For Nursing Students Based On Need Analysis In Indonesia. ELT Worldwide, 4(1), 61-74.

Bernardo, A. B., \& Gaerlan, M. J. M. (2012). Non-Native English Students Learning In English: Reviewing And Reflecting On The Research.

Brown, J. D. (1995). The Elements Of Language Curriculum: A Systematic Approach To Program Development. Boston: Heinle And Heinle.

Bushgjokaj, A. (2013). International Conference: New Perspectives In Science Education. The Importance Of English For Science Teachers: In The Albanian Context (2nd Ed.).

Burdova, V. (2007). English For Specific Purposes (Tourist Management And Hotel Industry) Department Of English Language And Literature Masaryk University.

Coleman, H. (2011). Developing Countries And The English Language: Rhetoric, Risks, Roles And Recommendations. Dreams And Realities: Developing Countries And The English Language, 9-22.

Dewi, S. U. (2015). Syllabus Of Vocational High School Based On ESP Approach. Dinamika Ilmu, 15(2), 273-295.

DR. SUYADI, S. P., M.A. (2016). "English for Specific Purposes for Accounting Students." International Journal of Innovation and Research in Educational Sciences 3 (2). 
Duddley-Evans, T. (2000). Teaching English For Specific Purposes. ELT Journal, 44(4), 261-270.

Ellis, R. 1985. Understanding Second Language Acquisition. Oxford: Oxford University Press.

Graves, K. (2000) Designing Language Courses. Boston: Heinle \& Heinle Publishers

Gass, J. (2012). "Need Analysis and Situational Analysis: Designing an ESP Curriculum for Thai Nurses." 12 (36).

Hutchinson, T. \& Waters, A. (1987). English For Specific Purposes: A Learning Centered Approach. New York: Cambridge University Press

Kenyatta University, Kenyatta University.

Marwan A (2009). ESP Teaching Challenges In An Indonesian Vocational Higher Institution. The Engl. Teacher. 38:1-12.

Mulleneaux, A. (2017). English for Specific Purposes (ESP): Which Linguistic Skills Improve and which do not Improve throughout the Duration of an ESP Class?, St. Cloud State University. Master of Arts.

Munby, J. (1978). Communicative Syllabus Design. Cambridge: Cambridge University Press.

Nunan, D. (1988) The Learner-Centred Curriculum. Cambridge: Cambridge University Press.

Orangee I, D. O. (2013). A Needs Analysis Of Business English Programme For Tour Guide Diploma Students In Kenya. Department Of English And Linguistics

Poedjiastutie, D. (2017). The Pedagogical Challenges Of English For Specific Purposes (ESP) Teaching At The University Of Muhammadiyah Malang, Indonesia. Educational Research And Reviews, 12(6), 338.

Popa, D. E. (2013). "Medical Discourse and ESP Courses for Romanian Nursing Undergraduates ": 17-24.

Richards, J. (2001) Curriculum Development In Language Teaching. Cambridge: Cambridge University Press.

Richards, J. C., \& Schmidt, R. W. (2013). Longman Dictionary Of Language Teaching And Applied Linguistics. Routledge.

Saragih, E. (2014). Designing ESP Materials For Nursing Students Based On Needs Analysis. International Journal Of Linguistics, 6(4), 59-70.

Thanky, P. (2014). Importance Of English And Communication Skills For Technical Professionals. International Journal Of Science Research, 3(4), 211-212.

Triton. (2006). Journal Of Community \& Applied Social Psychology. Community Appl. Soc. Psychol., 16: 59-69 (2006) Published Online In Wiley Inter Science (Www.Interscience.Wiley.Com). DOI: 10.1002/Casp.849 
West, R. (1994). Needs Analysis In Teaching. Language Teaching, 27(1), 1-19

Yoyok Febrijanto, S. K. (2017). "Developing Esp Nursing Based On Communicative Language Teaching." Journal Of Teaching And Research 2.

Zuana., M. M. M. (2014). "The Role Of Need Analysis In Teaching Esp For Nursing " The 61 Teflin International Conference. 